\section{Slow Crawl Across the Salinity Divide: Delayed Colonization of Freshwater Ecosystems by Invertebrates}

\author{
Molly Fritz Miller, Geology Department, Box 117 Station B, Vanderbilt University, \\ Nashville, Tennessee 37235, USA,molly.f.miller@vanderbilt.edu \\ Conrad C. Labandeira, Department of Paleobiology, National Museum of Natural \\ History, Smithsonian Institution, Washington, D.C. 20560-0121, USA, \\ labandeira.conrad@nmnh.si.edu
}

\section{ABSTRACT}

Ecologically complex communities occupied marine habitats $<100$ m.y. after the first appearance of multicellular animals during the Ediacaran Period of the late Neoproterozoic. By contrast, freshwater habitats, particularly habitats within the substrate, remained mostly uninhabited for another 200 m.y. This delayed colonization of freshwater substrate ecospace is reflected by the small amount of bioturbation in Upper Carboniferous to Triassic freshwater deposits and in the records of body and trace fossils. Terrestrial insects invaded some freshwater habitats left open by the paucity of immigrants from the ocean during the late Paleozoic, but insects did not inhabit the substrate extensively until later in the Mesozoic. Marine invertebrates were slow to acquire the osmoregulatory capabilities and reproductive and dispersal mechanisms characteristic of successful freshwater animals.

Compared to modern marine benthic communities and animal-substrate relations, those in fresh water are poorly known. Pristine conditions have been modified by human activities, and human-aided transport has facilitated rapid invasion of some marine animals into fresh water, where they have adapted quickly. Study of the genetic and physiologic changes in animals that have invaded fresh water in historical time may elucidate the macroevolutionary processes that controlled the colonization of fresh water through the Phanerozoic.

\section{INTRODUCTION}

How does the colonization history of freshwater habitats, particularly that of sand or mud substrates, compare to that of soft bottom habitats in the marine realm?
In $<100$ m.y. from the late Neoproterozoic (600 m.y. ago) into the Cambrian, marine animal life appeared and burgeoned from a few animals with a limited range of body plans and life styles of the Ediacaran fauna (e.g., Narbonne, 1998) to ecologically diverse faunas with representatives from all major phyla, including chordates, of the Chengjiang and Burgess Shale biotas (Briggs et al., 1994; Bowring and Erwin, 1998; Babcock et al., 2001). During this time, algal mats on the sediment surface were consumed by increasingly abundant and diverse grazers and burrowers. As a result, the firm algalbound substrates of the Neoproterozoic were replaced by the easily resuspended surfaces of sediment present today and throughout the Phanerozoic (Bottjer et al., 2000).

Ichnofabric, the texture imparted to sedimentary rocks by biologic activity
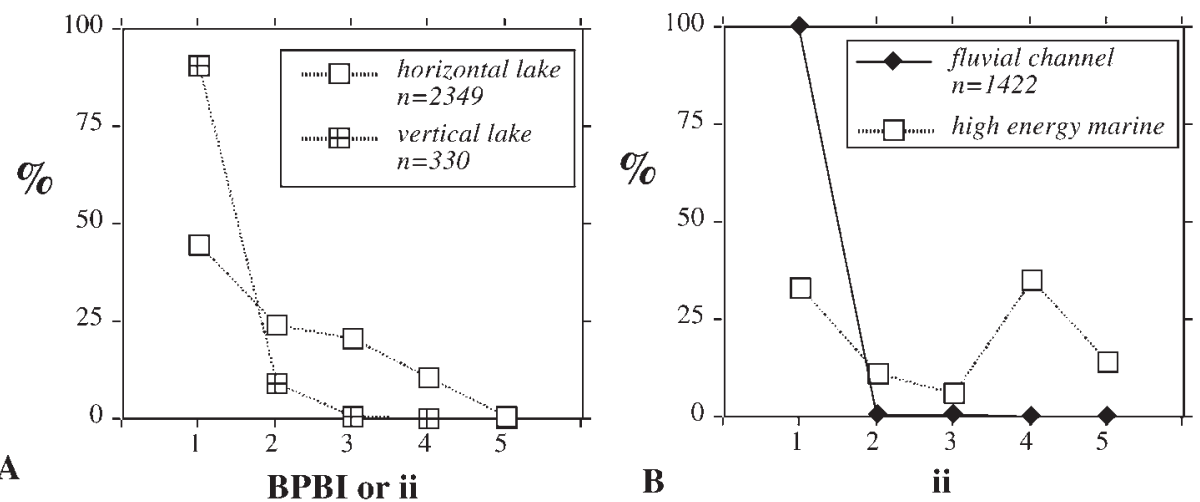

Figure 2. Percent of observations in each category of bioturbation on either bedding planes (BPBI) or vertical surfaces (Ichnofabric Indices, ii, Droser and Bottjer, 1986). Categories of ii are the same as for BPBI (Fig. 1). A: Vertical (ii) vs. horizontal bioturbation (BPBI) in lake deposits. B: Bioturbation in high-energy fluvial and marine sandstones. Data for fluvial channels are from Miller et al. (2002). Data for marine deposits are from Droser and Bottjer (1990) and are averages of ichnofabric values for $10 \mathrm{~m}$ of vertical sections of Cambrian, Ordovician, and Silurian high-energy nearshore sandstones. Paucity of bioturbation in Permian-Jurassic fluvial channels contrasts with the relative abundance of high levels of bioturbation in lower Paleozoic marine sandstones. 
Early Ordovician or earlier, sediments in diverse marine environments were highly bioturbated to depths of $10 \mathrm{~cm}$ or more (Miller and Byers, 1984; Droser et al., 1994).

Lakes and streams are aquatic habitats that are connected to oceans. If all major phyla appeared and marine habitats were colonized within $<100$ m.y. after the first appearance of multicellular animals 600 m.y. ago, one would predict that lakes and streams would similarly have been invaded relatively quickly by invertebrates. Accordingly, this paper synthesizes available data from the ichnofabric and body fossil records about the colonization history of freshwater habitats and demonstrates that substrate ecospace in streams and lakes was barely used for $\sim 200$ m.y. after the rapid colonization of marine habitats. We suggest factors that might have inhibited colonization of fresh water, and we raise questions about the extent to which modern freshwater substrate ecospace is used. Additionally, we point out limitations in current understanding of modern freshwater benthic communities and of the potential for study of modern freshwater invaders to clarify the macroevolutionary processes involved in the early colonization of freshwater habitats.

\section{RECORD OF FRESHWATER INVERTEBRATES}

\section{Trace Fossil and Bioturbation Record}

The $4 \mathrm{~km}$ thick sequence of diverse freshwater facies of Permian to Jurassic age that are extensively exposed in the Transantarctic Mountains provides a perfect laboratory for evaluating substrate ecospace use by aquatic animals. Using pattern recognition methods, we assessed semiquantitatively the amount of bioturbation on bedding plane and vertical surfaces of subaqueous floodplain, fluvial channel, and lacustrine facies (Miller et al., 2002). We found that (1) the amount of bioturbation is very low, although it varies with facies, and (2) bioturbation is more intense on horizontal than vertical exposures, indicating that animal activity was confined to the surface rather than penetrative. Overall, $67 \%$ of observations of bedding planes showed no bioturbation; lake siltstones were the most disrupted and fluvial channel sandstones the least (Fig. 1). Within each facies, horizontal rather than vertical bioturbation is more intense

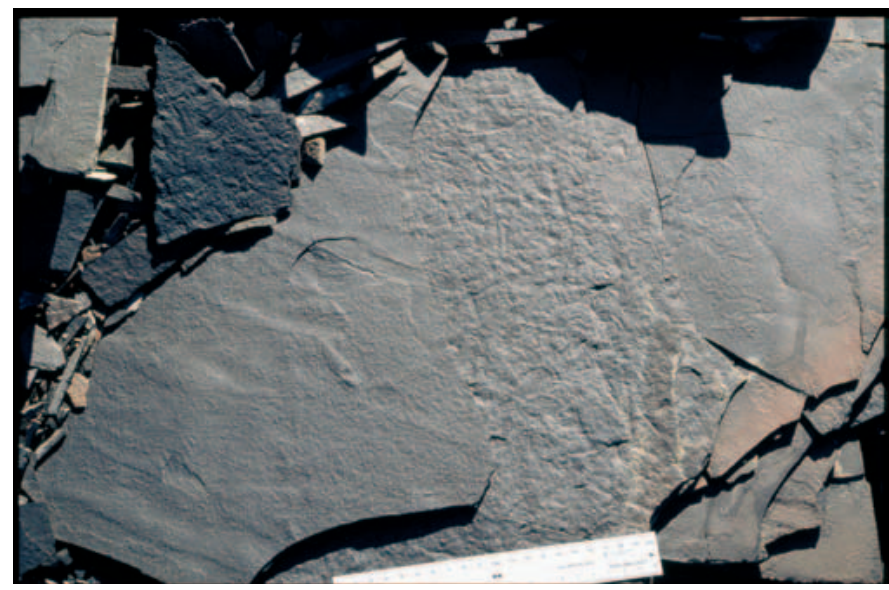

Figure 3. Lacustrine siltstone showing different amounts of bioturbation on closely spaced bedding planes, indicating that the animals were not penetrating the sediment (Permian Mackellar Formation, Transantarctic Mountains, Miller et al., 2002).

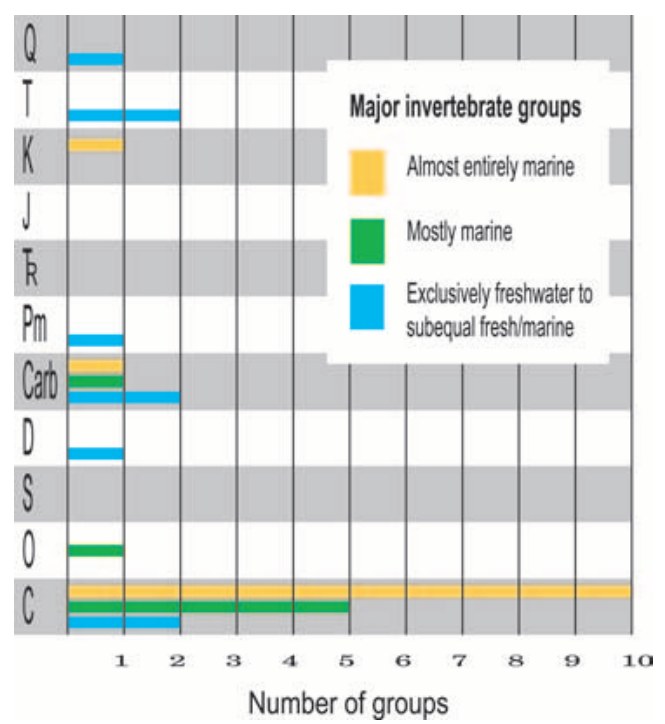

Figure 4. First appearances of almost entirely marine, mostly marine, and freshwater (to subequally freshwater and marine) groups from Pennak (1989) and Conway-Morris (1993.)

(Fig. 2A). Dissection of laminae from lacustrine siltstones demonstrates that the amount of horizontal bioturbation varies between laminae separated by only a few millimeters, indicating that animals clearly did not use the entire substrate ecospace (Fig. 3). In contrast, available data from marine facies indicate much higher levels of bioturbation than in freshwater facies even in much older rocks (Figs. 1, 2B).

The trace fossil record is consistent with these bioturbation data in demonstrating that freshwater animals lived on or near the top of the sediment during the middle to late Paleozoic. Predominantly surficial trails and trackways in Devonian fluvial and shallow lake deposits probably were produced by arthropods (Miller, 1984a). Surface traces characterize Pennsylvanian and Permian lacustrine beds (Maples and Archer, 1989; Pickerill, 1992; Buatois and Mángano, 1995), although deeper burrows occur in fluvial facies (Fitzgerald and Barrett, 1986). Most of these arthropod traces are considered to have been insect-produced and are attributed, with varying degrees of certitude, to adult bristletails, the naiads (aquatic nymphs) of mayflies (Ephemeroptera), dragonflies (Odonatoptera), stoneflies (Plecoptera), and occasional protorthopterans (Braddy, 1998; Braddy and Briggs, 2002). The diversity of subaqueously produced trace fossils increases during the Triassic through Jurassic, as does depth of burrow penetration (Bromley and Asgaard, 1979; Gierlowski-Kordesch, 1991; Metz, 1996; Buatois et al., 1998).

\section{Body Fossil Record}

All Invertebrates. Currently there are more higher groups of marine invertebrates than freshwater invertebrates (Fig. 4). Freshwater groups appeared in the fossil record after marine groups. In part, this reflects poor preservation potential of freshwater animals that typically lack a hard skeleton and live in habitats dominated by long-term erosion rather than deposition. However, the fact that four of the 15 marine groups present by the end of the Cambrian are soft-bodied implies controlling factors beyond preservation potential alone. A plot of the first 


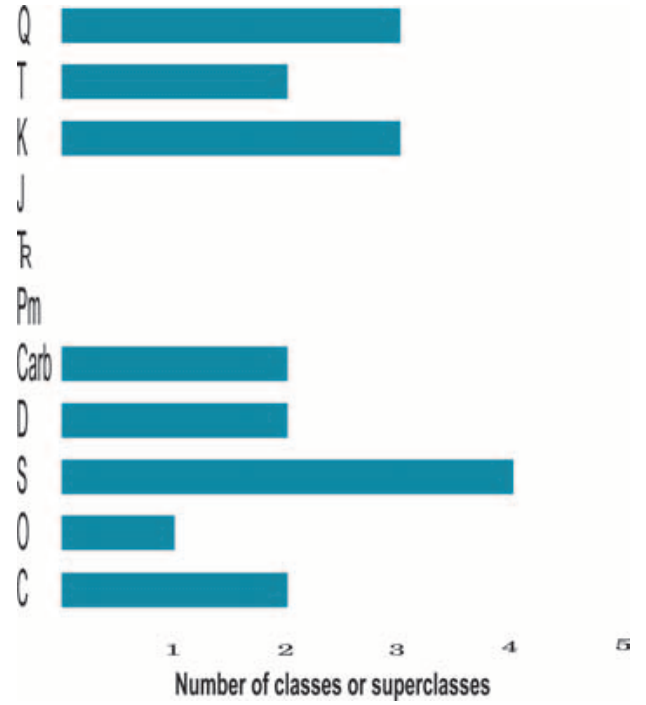

Figure 5. First appearances of superclasses or classes of freshwater animals (from Gray, 1988).

occurrences in fresh water of superclasses and classes of invertebrates as compiled by Gray (1988) yields a similar pattern. Rather than proliferation of many groups before or during the Cambrian, the first appearances of higher taxa in freshwater deposits are spread throughout the Phanerozoic (Fig. 5), albeit with a lack of occurrences during the Permian to Jurassic.

Freshwater burrowers. The most common burrowers in modern freshwater substrates are insects, mostly as immature stages and less frequently as adults, and subordinately oligochaetes (earthworms). The oldest putative oligochaete occurs in Carboniferous rocks, but its identity is disputed (Conway-Morris et al., 1982); a later first appearance, particularly of burrowing taxa, is consistent with a recent phylogenetic analysis of annelids (Brinkhurst and Gelder, 2001). Crayfish date back to the Triassic; although they burrow through subaerial floodplain deposits in order to reach the water table, they generally do not burrow in lakes and streams.

Modern taxonomic orders of insects with one or more aquatic stage appeared between the Permian, perhaps Late Carboniferous (Kukalová-Peck, 1983), and the Jurassic (Fig. 6; Wootton, 1988; Sinichenkova and Zherikhin, 1996; Ponomarenko, 1996; Fraser et al., 1996). An aquatic lifestyle for several lineages of Permian insects is demonstrated by presence of abdominal gills, and their dorso-ventral flattening indicates that they were epibenthic, living on top of the sediment (Tillyard, 1935; Tschernova, 1965; Kukalová, 1968; Sinichenkova, 1987; Wootton, 1988). Most early aquatic insects probably were predators living on the bottom based on mouthpart structure and inclusion in taxa with known modern diets (Tschernova, 1965; Kukalová, 1968; Wootton, 1988). These taxa constitute a major dietary guild that continued throughout the Mesozoic (Ponomarenko, 1996; Sinichenkova and Zherikhin, 1996) and to the present. By contrast, benthic filter feeding and deposit feeding within the sediment- the preferred feeding habits of burrowers-were not established until the Late Triassic and Early Jurassic, respectively (Wootton, 1988).

Delayed colonization of habitable space within freshwater substrates until the mid Mesozoic also is indicated by the first occurrences of modern insect families with representatives that burrow in freshwater sediments (Fig. 6). Families with burrowers were identified in tables summarizing the ecology of modern aquatic insects (Merritt and Cummins, 1996) and their first occurrences are recorded by an update of Labandeira's compendium (1994) that documents the geochronological occurrences of fossil insects. Modern families with insect burrowers evolved after the origin of their respective orders, supporting Wootton's (1988) inference that infaunal life styles were the last to arise in aquatic insects. Thus the body-fossil record of modern burrowers, particularly of insects, supports the important conclusion from ichnofabric and trace fossils that freshwater epibenthic habitats at best were modestly occupied during the Permian, but ecospace below the substrate surface was not extensively inhabited until significantly after the late Paleozoic.

\section{ROUTES TO FRESH WATER}

Animals living in freshwater habitats were evolutionarily derived from (1) marine groups that adapted to reduced salinity as they moved upstream through estuaries into fresh water, and (2) air-breathing terrestrial groups such as insects that secondarily invaded aquatic habitats by transformation of structures into gills or by various behavioral and physiological adaptations (Edney, 1977; Pennak, 1989; Labandeira and Beall, 1990; Little, 1990).

A common pattern is invasion of fresh water by one to several groups within a major taxon, each of which independently adapted to freshwater conditions and each of which includes a limited number of genera and/or species (Hutchinson, 1967). For example, the Phylum Cnidaria consists of animals that vary widely in morphology and life style and that are grouped into three classes: Anthozoa (corals, sea anemones), Scyphozoa (true jellyfish), and Hydrozoa (hydroids, stinging corals, Portugueseman-of-war). Freshwater cnidarians are almost exclusively confined to a few genera in one small family of one order in the Class Hydrozoa, but the genera, particularly Hydra, are geographically widespread and abundant (Hutchinson, 1967;

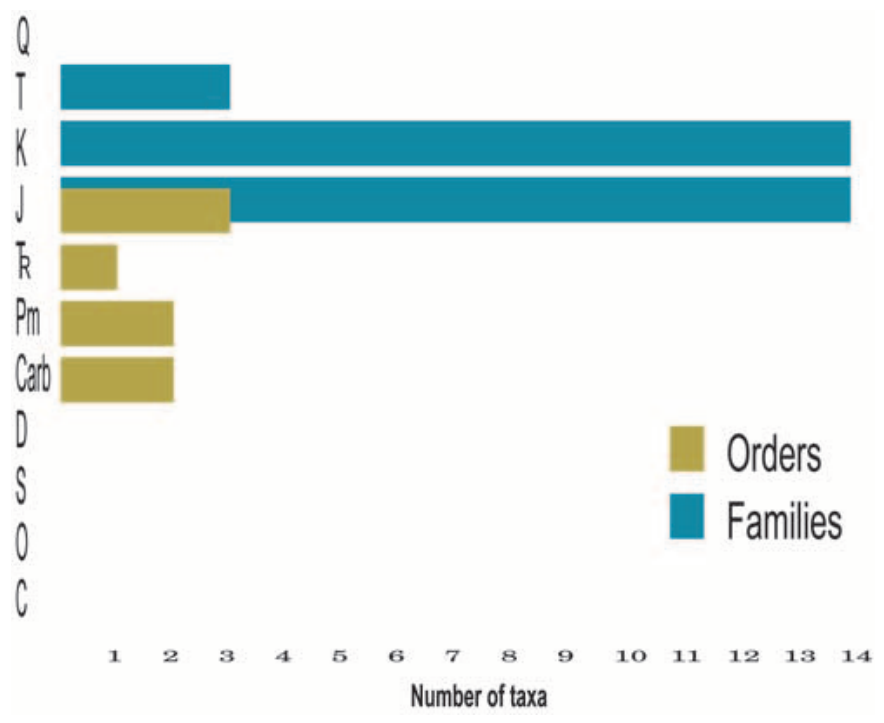

Figure 6. First appearances of modern aquatic insect orders (from Wootton, 1988) and of modern families with burrowers in aquatic sediments (from Merritt and Cummins, 1996, and Labandeira, 1994). 
Slobodkin and Bossert, 2001). It is not known what physiological adaptation facilitated colonization and proliferation of the Hydridae in fresh water, nor is it known why only one other order in the Class Hydrozoa and no orders in the Classes Anthozoa or Scyphozoa became adapted to life in fresh water.

The pattern of multiple invasions of fresh water by small groups is also seen in clams and snails. The estimated number of independent invasions of fresh water by marine bivalves is 12 , but five of these added only a single genus to the freshwater fauna (Hutchinson, 1967). Similarly, freshwater gastropod species belong to 15 families, 11 of which have five or fewer genera (Brown, 2001).

The earliest known Devonian insects were clearly terrestrial and lacked wings (Labandeira et al., 1988). Although it has been suggested that winged insects were derived from aquatic ancestors (Kukalová-Peck, 1983; Toms, 1984; Thomas et al., 2000), the consensus now is that all insects, including those with wings, evolved on land and were equipped with tracheae for respiration in air and that water-dwelling insects are secondarily aquatic (Ward, 1992; Pritchard et al., 1993; D'Haese, 2002). Thus insects, so dominant in the faunas of lakes and streams, invaded fresh water from land rather than from the sea.

\section{BARRIERS TO COLONIZATION OF FRESHWATER HABITATS \\ What's to Eat?}

If vascular land plants did not appear and diversify until the Late Silurian to Devonian (Edwards and Wellman, 2001; Kotyk et al., 2002), the lack of food resources would have delayed freshwater colonization, particularly of substrate ecospace (Maples and Archer, 1989). However, there is increasing evidence that establishment of vascular plant communities was the third and final stage in the colonization of terrestrial habitats by plants (Gray, 1993; Strother, 2000). It was preceded by a microbial phase in the Precambrian to Cambrian and a moss-liverwort phase in the Cambrian to Silurian characterized by simple ecosystems and some plant cover (Strother, 2000; Retallack, 2000). In addition to land-derived plant material, at least in terrestrial environments bordering coastlines, nearby lakes and streams probably had microbial and algal food sources (Gray, 1993), and stromatolites occur in Precambrian freshwater deposits (Hoffman, 1976; Awramik, 1984). In modern ecosystems the importance of land-derived

detritus versus water-derived detritus for microbial food sources varies along the length of river systems and in different parts of lakes (Wotton, 1994; Thorp and Covich, 2001) and the same probably was true in the mid to late Paleozoic.

Although live plant tissues and detritus from late Paleozoic forests provided a food bonanza for arthropod herbivores and detritivores (Labandeira et al., 1997; Labandeira, 1998; Roßler, 2000; Raymond et al., 2000), land-plant organic matter also presented a nutritional and biochemical challenge to aquatic animals. The structural rigidity needed to maintain a tree in an upright position originates from materials such as lignin and cellulose that are refractory and difficult to break down, in contrast to microbial and aquatic plant material. Animals dependent on such refractory organic matter commonly have extra enzymes, gut microbes, or behavioral modifications to facilitate their conversion to a usable form; acquisition of these features required evolutionary adaptation on land or in water (Lamberti and Moore, 1984; Hunt and Nalepa, 1994; Giller and Malmquist, 1998). Nevertheless, an ecologically extensive array of plantconsuming mites and insects was present on land during the late Pennsylvanian and Early Permian, representing colonization of communities such as woodlands along streams and peat-dominated swamp forests by distinctive feeding groups of herbivores and detritivores that had specialized morphological adaptations for chewing, piercing, boring, galling, and consuming pollen and spores (Beck and Labandeira, 1998; Labandeira, 1998; Raymond et al., 2000).

\section{Barriers Along the Marine $\rightarrow$ Fresh Water Route}

The composition of body fluids of marine animals is similar to that of seawater, but body fluids of freshwater animals are much saltier than the water that surrounds them. Consequently there is a strong osmotic gradient with water flowing into the animal across all permeable surfaces (Little, 1990). In general, freshwater animals maintain constant concentration of body fluids by limiting permeability of surfaces, and, unlike marine animals, by secreting highly dilute urine; they also are able to absorb salts that are in very low concentration in fresh water (Pennak, 1989). Maintaining this osmoregulatory system is energetically expensive and requires physiological adaptations from the cellular to organal levels. Along the marine to brackish to fresh aquatic continuum, by far the smallest number of species occurs in brackish waters (salinity of 7\%0-10\% ; Pennak, 1989). Thus estuaries, characterized by both low and fluctuating salinities, effectively serve as ecological and taxonomic filters and barriers to marine species.

Optimal strategies for reproduction and dispersal differ for marine versus freshwater macroinvertebrates, for which an adjustment presents challenges to potential invaders from the sea. Marine animals commonly produce large numbers of planktic larvae which may be widely dispersed in the oceans (Scheltema, 1971).

This strategy is rare in fresh water, probably because favorable habitats are spatially fragmented and because small planktic larvae with large surface areas would face potentially insurmountable osmoregulatory problems in fresh water. In general, freshwater animals lack planktic larval stages and produce fewer and much larger eggs that are brooded rather than broadcast (Pennak, 1989). Unionid clams, probably present in fresh water since the late Paleozoic, have responded to dispersal challenges by developing a larval form that is temporarily parasitic on fish. Such innovations imply significant evolutionary change for adaptation to fresh water.

\section{Barriers Along the Terrestrial $\rightarrow$ Fresh Water Route}

Insects and pulmonate snails colonized fresh water from terrestrial habitats. Pulmonate snails have a vascularized mantle cavity that functions as a lung. Some aquatic pulmonates have a secondarily derived gill within the mantle cavity for obtaining oxygen from water. By contrast, terrestrial insects have a tracheal system to efficiently obtain oxygen from air, but are encased in a fairly impermeable exoskeleton that reduces water loss. In fully aquatic insects the tracheal system is modified and used for distribution of gases, the exoskeleton is reduced to facilitate uptake of oxygen, and commonly 
there are external respiratory epithelia deployed as gills. These modifications have been accomplished in a variety of styles in different insect groups (Ward, 1992; Wichard et al., 2002). Alteration of the respiratory systems in these two groups required significant evolutionary change. Additionally, in insects, other structural, physiological, and behavioral changes have resulted in the colonization of freshwater ecosystems. For example, eggs are inserted into such unconventional substrates as internal stem tissues of submergent plants in the case of dragonflies (Corbet, 1999).

\section{Special Challenges Faced by Burrowers}

The sediment in which animals burrow is more likely than the overlying water to become depleted in oxygen, especially if it contains much organic matter. Burrowers in sand and mud have adaptations for obtaining or using oxygen efficiently. Some burrowing dragonfly naiads have long respiratory siphons (Ward, 1992), but most burrowing insects, such as certain mayfly naiads, have gills rather than respiratory siphons, and bear special hairs on shields that are needed to keep respiratory surfaces from being covered with sediment (Wichard et al., 2002).

Burrowers in shifting sand substrates are prone to exhumation and/or burial by sediment. The premiere marine burrowers are crustacean callianassid shrimp; some populations can overturn a layer $30 \mathrm{~cm}$ thick in less than 40 days (Miller, 1984b). They owe their burrowing prowess to highly modified leg appendages which freshwater insects rarely have.

\section{WERE THE BARRIERS OVERCOME? Yes}

The very presence of freshwater animals derived from marine ancestors demonstrates that the barriers along the marine to freshwater route were surmountable (Edney, 1977; Little, 1990). Representatives of numerically many, but a small percentage, of marine taxa independently developed the osmoregulatory systems and reproductive or dispersal strategies needed for success in fresh water.

\section{Gradually}

The dominance of insects in freshwater habitats underscores the slowness of marine animals in crossing the salinity barrier. Insect invasion from terrestrial environments was permitted because ecospace was still available as marine animals struggled and straggled across the salinity divide through the Paleozoic. The diversity and abundance of aquatic insects, and to a lesser extent pulmonate snails, testify to their success in crossing barriers along the terrestrial to fresh water route.

\section{IS SUBSTRATE ECOSPACE FULLY OCCUPIED IN MODERN LAKES AND STREAMS? \\ No?}

Sand depleted in organic matter and mud bottoms of streams and lakes have depauperate insect faunas and few individuals (Ward, 1992), although the data are relatively poor. Cobble substrates with plant debris have one order of magnitude more insects. Because the few burrowers in sand and mud are usually very small in size, much of this ecospace is empty.

The very existence of varves in lacustrine deposits also implies absence of infaunal animals disrupting and churning the sediment. The fact that detailed Quaternary climate histories can be reconstructed on the basis of pollen and insect remains preserved in thin laminae in lake-bottom sediments attests to absence of disruption by burrowing animals that in some cases is not due to low oxygenic conditions (Cohen, 1984; Bennike, 2000).

\section{Yes?}

Insects, oligochaetes, clams, and amphipods mix sediment of the Great Lakes to a depth of 5 to $10 \mathrm{~cm}$, which affects both the physical and chemical characteristics of the sediment (e.g., McCall and Tevesz, 1982; Fisher, 1982). Recent laboratory work has documented the rates at which freshwater burrowers transport materials within the sediment, across the sediment-water interface, and the depth to which they rework sediment (see references in Charbonneau and Hare, 1998; Miller et al., 2002). If animals occur commonly in the high densities recorded, and if they are as active in natural settings as they are in laboratory conditions, the substrate ecospace of modern lakes and streams is extensively used.
Too little is known about freshwater animal-sediment relations to generalize

With the exception of the Great Lakes, lake bottoms and their inhabitants are barely explored. The same is true of large rivers, which as of 1989 were the subject of only $4 \%$ of papers on fluvial ecology (Thorp and Covich, 2001). It is particularly difficult to generalize about the use of substrate ecospace because bottom dwelling animals are patchily distributed and their substrates are heterogeneous (Brinkhurst, 1974; Beckett et al., 1983).

In contrast, the bottoms of the world's oceans have been cored and box cored extensively, documenting the pervasive use of the substrate ecospace (Howard and Reineck, 1972; Ekdale and Berger, 1978). Unfortunately, equivalent understanding of pristine benthic habitats in fresh water may not be possible due to anthropogenically induced invasions by exotic species and pollution in lakes, and to modification of substrate characteristics caused by channelization of large rivers (Thorp and Covich, 2001).

\section{MORE RECENT INVASIONS}

Invasion of freshwater habitats by some marine animals belonging to groups with freshwater representatives has occurred during the last few million years, especially in tropical areas (Pennak, 1989; Diesel et al., 2000; Vermeij and Wesselingh, 2002). In the last $150 \mathrm{yr}$, freshwater invasion by marine species has increased, particularly in reservoirs and polluted rivers. This is probably a result of human and climate-related reduction in indigenous faunas coupled with human-provided opportunities for dispersal (Lee and Bell, 1999). These authors have identified common characteristics of these invaders that facilitated the transition to fresh water, including high rates of growth and reproduction, but identification of the ultimate causes of successful invasions has remained elusive. It also is not known if these invaders will persist over geologic time.

The frequency and speed of the invasions is striking (Lee, 1999). One-third of the 139 exotic aquatic organisms in the Great Lakes, many of them of marine origin, have been introduced since 1960 (Mills et al., 1993). Morphological adaptations can occur within decades after introduction (Klepaker, 1993). Such rapid adaptation provides a unique opportunity 
to identify and explore the genetic and physiological changes that are associated with colonization of fresh water. Given the present state of knowledge, it remains puzzling why invasion of fresh water appears so easy now but so difficult in the past. In addition to elucidating human impact on freshwater ecosystems, more extensive study of human-aided invasions in historical time may lead to better understanding of why freshwater habitats were so slow to be colonized so many tens of millions of years after the rapid establishment of diverse marine communities during the Cambrian.

\section{CONCLUSIONS}

Freshwater habitats were very slowly colonized over hundreds of millions of years during the late Paleozoic, in contrast to marine habitats that were invaded quickly in the Cambrian by many different animals with diverse lifestyles.

Terrestrial plant communities were ecologically colonized and partitioned by insect herbivores and detritivores during the late Pennsylvanian to Early Permian, significantly before the occupation of freshwater habitats. Eventually, the freshwater ecospace left open by a paucity of colonizers from the sea was gradually invaded by insects from land during and after the Permian.

Colonization of fresh water by marine animals may have been slowed by the need to develop more complex osmoregulatory systems and different styles of reproduction and dispersal. To use freshwater ecospace, burrowing insects needed new and efficient means of obtaining oxygen, handling sediment, and completing their reproductive cycle. Although animals overcame the barriers to fresh water, it is not well documented that they ever used the substrate ecospace as effectively and completely as marine animals.

During the past 150 years many human-transported marine invaders have adapted to fresh water. Documentation of the genetic and physiological changes occurring now may help understand the processes that were involved in the largescale colonization of freshwater habitats.

\section{ACKNOWLEDGMENTS}

This work is supported by National Science Foundation grants OPP9417978 and OPP 9614709 to Miller, and the Walcott Fund and Scholarly Studies
Program of the Smithsonian Institution to Labandeira. We thank H. Allen Curran, A.A. (Tony) Ekdale, Karl E. Karlstrom, and L. David Smith for helpful comments on an earlier version of this manuscript.

\section{REFERENCES CITED}

Awramik, S.M., 1984, Ancient stromatolites and microbial mats, in Cohen, Y., Catenholz, R.W., and Halvorson, H.O. eds., Microbial mats, stromatolites: New York, Liss, p. 1-22.

Babcock, L.E., Zhang, W., Leslie, S.A., 2001, The Chengjiang Biota: Record of the Early Cambrian diversification of life and clues to exceptional preservation of fossils: GSA Today, v. 11, no. 2, p. 4-9.

Beck, A., and Labandeira, C.C., 1998, Early Permian insect folivory on a gigantopterid-dominated riparian flora from north-central Texas: Palaeogeography, Palaeoclimatology, Palaeoecology, v. 142, p. 139-173.

Beckett, D.C., Bingham, C.R., and Sanders, L.G., 1983 Benthic macroinvertebrates of selected habitats of the Lower Mississippi River: Journal of Freshwater Ecology, v. 2 p. 247-261.

Bennike, O., 2000, Paleoecological studies of Holocene lake sediment from west Greenland: Palaeogeography, Palaeoclimatology, Palaeoecology, v. 155, p. 285-304.

Bottjer, D.J., Hagadorn, J.W., and Dornbos, S.Q., 2000, The Cambrian substrate revolution: GSA Today, v. 10, no. 9, p. 1-7.

Bowring, S.A., and Erwin, D.H., 1998, A new look at evolutionary rates in deep time: Uniting paleontology and high-precision geochronology: GSA Today, v. 8, no. 7, p. 1-8.

Braddy, S.J., 1998, An overview of the invertebrate ichnotaxa from the Robledo Mountains ichnofauna (Lower Permian), southern New Mexico: New Mexico Museum of Natural History and Science Bulletin, v. 12, p. 93-98.

Braddy, S.J., and Briggs, D.E.G., 2002, New Lower Permian nonmarine arthropod trace fossils from New Mexico and South Africa: Journal of Paleontology, v. 76, p. 546-557.

Briggs, D.E.G., Erwin, D.H., and Collier, F.J., 1994, The fossils of the Burgess Shale: Washington, Smithsonian Institution Press, $238 \mathrm{p}$.

Brinkhurst, R.O., 1974, The benthos of lakes: New York, St. Martin's Press, $182 \mathrm{p}$

Brinkhurst, R.O., and Gelder, S.R., 2001, Annelida: Oligochaeta, including Branciobdellidae, in Thorp, J.H., and Covich, A.P., eds., Ecology and classification of North American freshwater invertebrates, 2nd edition: San Diego, Academic Press, p. 431-463.

Bromley, R.G., and Asgaard, U., 1979, Triassic freshwater ichnocoenoses from Carlsberg Fjord, East Greenland: Palaeogeography, Palaeoclimatology, Palaeoecology, v. 24 p. 39-80.

Brown, K.M., 2001, Mollusca: Gastropoda, in Thorp, J.H., and Covich, A.P., eds., Ecology and classification of North American freshwater invertebrates, 2nd edition: San Diego, Academic Press, p. 297-329.

Buatois, L.A., and Mángano, M.G., 1995, The paleoenvironmental and paleoecological significance of the lacustrine Mermia ichnofacies: an archetypical subaqueous nonmarine trace fossil assemblage: Ichnos, v. 4, p. 151-161.

Buatois, L.A. Mángano, M.G. Genise, J.F., Taylor, T.N., 1998, The ichnological record of the continental invertebrate invasion: evolutionary trends in environmental expansion, ecospace utilization, and behavioral complexity: Palaios, v. 13 , p. $217-240$.

Charbonneau, P., and Hare, L., 1998, Burrowing behavior and biogenic structures of mud dwelling insects: Journal of the North American Benthological Society, v. 17, p. 239-249.

Cohen, A.S., 1984, Effect of zoobenthic standing crop on laminae preservation in tropical lake sediment, Lake Turkana, East Africa: Journal of Paleontology, v. 58, p. 499-510.

Conway-Morris, S., 1993, The fossil record and the early evolution of the Metazoa: Nature, v. 361, p. 219-225.

Conway-Morris, S., Pickerill, R.K., and Harland, T.L., 1982, A possible annelid from the Trenton Limestone (Ordovician) of Québec, with a review of fossil oligochaetes and other annu- late worms: Canadian Journal of Earth Sciences, v. 19, p. 2150-2157.

Corbet, P.S., 1999, Dragonflies—behaviour and ecology of Odonata: Colchester, U.K., Harley Books, 829 p.

D'Haese, C.A., 2002, Were the first springtails semi-aquatic? A phylogenetic approach by means of $28 \mathrm{~s}$ rDNA and optimization alignment: Proceedings of the Royal Society of London (B), v. 269, p. 1143-1151.

Diesel, R., Schubart, C.D., and Schuh, M., 2000, A reconstruction of the invasion of land by Jamaican crabs (Grapsidae: Sesarminae): Journal of the Zoological Society of London, b. 250 , p. $141-160$.

Droser, M.L., and Bottjer, D.J., 1986, A semiquantitative field classification of ichnofabric: Journal of Sedimentary Petrology, v. 56 , p. $558-559$.

Droser, M.L., and Bottjer, D.J., 1990, Ichnofabrics of sandstones deposited in high-energy nearshore environments: Measurements and utilization: Palaios, v. 4, p. 598-604.

Droser, M.L., Gehling, J.G., and Jensen, S., 1999, When the worm turned: Concordance of Early Cambrian ichnofabric and trace-fossil record in siliciclastic rocks of South Australia: Geology, v. 27, p. 625-628.

Droser, M.L., Hughes, N.C., and Jell, P.A., 1994, Infaunal communities and tiering in early Paleozoic nearshore clastic environments: Trace fossil evidence from the CambroOrdovician of New South Wales: Lethaia, v. 27, p. 2273-2283.

Droser, M.L., and Li, Xing, 2001, The Cambrian radiation and the diversification of sedimentary fabrics, in Zhuravlev, A.Y., and Riding, R., eds., The ecology of the Cambrian explosion: New York, Columbia University Press, p. 137-169.

Edney, E.B., 1977, Water balance in land arthropods: Berlin, Springer-Verlag, $282 \mathrm{p}$.

Edwards, D., and Wellman, C., 2001, Embryophytes on land: the Ordovician to Lochkovian (Lower Devonian) record, in Gensel, P.G., and Edwards, D., eds., Plants invade the landevolutionary and environmental perspectives: New York, Columbia University Press, p. 3-28.

Ekdale, A.A., and Berger, W.H., 1978, Deep-sea ichnofacies: modern organism traces on and in pelagic carbonates of the western equatorial Pacific: Palaeogeography,

Palaeoclimatology, Palaeoecology, v. 23, p. 263-278.

Fisher, J.B., 1982, Effects of macrobenthos on the chemical diagenesis of freshwater sediments, in McCall, P.L., and Tevesz, M.J., eds., Animal-sediment relations: the biogenic alteration of sediment: New York, Plenum Press, p. 177-218.

Fitzgerald, P.G., and Barrett, P.J., 1986, Skolithos in a Permian braided river deposit, southern Victoria Land, Antarctica: Palaeogeography, Palaeoclimatology, Palaeoecology, v. 52, p. 237-247.

Fraser, N.C., Grimaldi, D.A., Olsen, P.E., and Axsmith, B., 1996, A Triassic Lagerstätte from eastern North America: Nature, v. 380, p. 615-619.

Gierlowski-Kordesch, E., 1991, Ichnology of an ephemeral lacustrine/alluvial plain system: Jurassic East Berlin Formation Hartford Basin, USA: Ichnos, v. 1, p. 221-232.

Giller, P.S., and Malmquist, B., 1998, The biology of streams and rivers: Oxford, Oxford University Press, 296 p.

Gray, J., 1988, Evolution of the freshwater ecosystem: the fossil record: Palaeogeography, Palaeoclimatology,

Palaeoecology, v. 62, p. 1-214.

Gray, J., 1993, Major Paleozoic land plant bio-events: Palaeogeography, Palaeoclimatology, Palaeoecology, v. 104, p. $153-169$.

Hoffman, P., 1976, Environmental diversity of middle Precambrian stromatolites, in Walter, M.F., ed., Stromatolites: Amsterdam, Elsevier, p. 599-611.

Howard, J.D., and Reineck, H.E., 1972, Physical and biogenic sedimentary structures of the nearshore shelf: Senckenbergiana Maritima, v. 4, p. 81-123.

Hunt, J.H., and Nalepa, C.A., 1994, Nourishment and evolution in insect societies: New Delhi, Oxford \& IBH Publishing Co., $449 \mathrm{p}$.

Hutchinson, G.E., 1967, A Treatise on limnology: vol. II, introduction to lake biology and the limnoplankton: New York, John Wiley \& Sons, 1115 p. 
Klepaker, T., 1993, Morphological changes in a marine population of threespined stickleback, Gasterosteus aculeatus, recently isolated in fresh water: Canadian Journal of Zoology, v. 71 , p. $1251-1258$.

Kotyk, M.W., Basinger, J.F., Gensel, P.G., De Freitas, T.A., 2002, Morphologically complex plant macrofossils from the Late Silurian of Arctic Canada: American Journal of Botany, v. 89, p. 1004-1013.

Kukalová, J., 1968, Permian mayfly nymphs: Psyche, v. 75 p. 310-327.

Kukalová-Peck, J., 1983, Origin of the insect wing and wing articulation from the arthropodan leg: Canadian Journal of Zoology, v. 61, p. 1618-1669.

Labandeira, C.C., 1994, A compendium of fossil insect families: Milwaukee Publication Museum Contributions in Biology and Geology, no. 88, 71 p.

Labandeira, C.C., 1998, Early history of arthropod and vascular plant associations: Annual Review of Earth and Planetary Sciences, v. 26, p. 329-377.

Labandeira, C.C., and Beall, B.S., 1990, Arthropod terrestriality, in Mikulic, D.G., ed., Arthropod Paleobiology: Short Courses in Paleontology, v. 3, p. 214-256.

Labandeira, C.C., Beall, B.S., Hueber, F.S., 1988, Early insect diversification: evidence from a Lower Devonian bristletail from Québec: Science, v. 242, p. 913-916.

Labandeira, C.C., Phillips, T.L., and Norton, R.L., 1997, Oribatid mites and decomposition of plant tissues in Paleozoic coal-swamp forests: Palaios, v. 12, p. 317-351.

Lamberti, G.A., and Moore, J.W., 1984, Aquatic insects as primary consumers, in Resh, V.H., and Rosenberg, D.M., eds., The ecology of aquatic insects: New York, Praeger

p. 164-195.

Lee, C.E., 1999, Rapid and repeated invasions of fresh water by the copepod Eurytemora affinis: Evolution, v. 53,

p. 1423-1434.

Lee, C.E., and Bell, M.A., 1999, Causes and consequences of recent invasions by saltwater animals: Trends in Ecology and Evolution, v. 14, p. 284-288.

Little, C., 1990, The terrestrial invasion: Cambridge, U.K., Cambridge University Press, $304 \mathrm{p}$.

Maples, C.G., and Archer, A., 1989, The potential of Paleozoic nonmarine trace fossils for paleoecological interpretations: Palaeogeography, Palaeoclimatology, Palaeoecology, v. 73 , p. $185-195$

McCall, P.L., and Tevesz, M.J., 1982, The effects of benthos on physical properties of freshwater sediments, in McCall,

P.L., and Tevesz, M.J., eds., Animals-sediment relations: The biogenic alteration of sediment: New York, Plenum Press, p. 105-176.

Mcllroy, D., and Logan, G.A., 1999, The impact of bioturbation on infaunal ecology and evolution during the Proterozoic-Cambrian transition: Palaios, v. 14, p. 58-72.
Merritt, R.W., and Cummins, K.W., 1996, An introduction to the aquatic insects of North America, 3rd edition: Dubuque, lowa, Kendall/Hunt Publishing, 862 p.

Metz, R., 1996, Newark Basin ichnology: The Late Triassic Perkasie Member of the Passaic Formation, Saratoga, Pennsylvania: Northeastern Geology, v. 18, p. 118-129.

Miller, M.F., 1984a, Distribution of biogenic structures in Paleozoic nonmarine and marine-margin sequences: an actualistic model: Journal of Paleontology, v. 58, p. 550-570. Miller, M.F., 1984b, Bioturbation in intertidal quartz-rich sands: a modern example and its sedimentologic and paleoecologic implications: Journal of Geology, v. 92, p. 201-216.

Miller, M.F., and Byers, C.W., 1984, Abundant and diverse early Paleozoic infauna indicated by the stratigraphic record: Geology, v. 12, p. 40-43.

Miller, M.F., McDowell, T.A., Smail, S.E., Shyr, Y., and Kemp N.R., 2002, Hardly used habitats: Dearth and distribution of burrowing in Paleozoic and Mesozoic stream and lake deposits: Geology, v. 30, p. 527-530.

Miller, M.F., and Smail, S.E., 1997, A semiquantitative field method for evaluating bioturbation on bedding planes: Palaios, v. 12, p. 391-396.

Mills, E.L., Leach, J.H., Carlton, J.T., Secar, C.L., 1993, Exotic species in the Great Lakes: a history of biotic crisis and anthropogenic introductions: Journal of Great Lakes Research, v. 19, p. 1-54.

Narbonne, G.M., 1998, The Ediacara Biota: A terminal Neoproterozoic experiment in the evolution of life: GSA Today, v. 8, no. 2, p. 1-6.

Pennak, R.W., 1989, Fresh-water invertebrates of the United States: Protozoa to Mollusca, 3rd edition: New York, John Wiley \& Sons, $628 \mathrm{p}$.

Pickerill, R.K., 1992, Carboniferous nonmarine invertebrate ichnocoenoses from southern New Brunswick, eastern Canada: Ichnos, v. 2, p. 21-35.

Ponomarenko, A.G., 1996, Evolution of continental aquatic ecosystems: Paleontological Journal, v. 30, p. 705-709.

Pritchard, G., McKee, M.H., Pike, E.M., Scrimgeour, G.J., and Sloty, J., 1993, Did the first insects live in water or in air? Biological Journal of the Linnean Society, v. 49, p. 31-44.

Raymond, A., Cutlip, P., and Sweet, M., 2000, Rates and processes of terrestrial nutrient cycling in the Paleozoic: The world before beetles, termites and flies, in Allmon, W.D., and Bottjer, D.J., eds., Evolutionary paleoecology: The ecological context of macroevolutionary change: New York, Columbia University Press, p. 235-283.

Retallack, G.J., 2000, Ordovician life on land and early Paleozoic global change, in Gastaldo, R.A., and DiMichele, W.A., eds., Phanerozoic terrestrial ecosystems: Paleontological Society Papers, v. 6, p. 21-45.

Roßler, R., 2000, The late Palaeozoic tree fern Psaronius — an ecosystem unto itself: Review of Palaeobotany and Palynology, v. 108, p. 55-74.
Scheltema, R.S., 1971, Larval dispersal as a means of genetic exchange between geographically separated populations of shallow-water benthic marine gastropods: Biological Bulletin v. 140 , p. $284-322$

Sinichenkova, N.D., 1987, The historical development of the Plecoptera: Transactions of the Paleontological Institute, v. 221, p. 1-142 (in Russian).

Sinichenkova, N.D., and Zherikhin, V.V., 1996, Mesozoic lacustrine biota: extinction and persistence of communities: Paleontological Journal, v. 30, p. 710-715.

Slobodkin, L.B., and Bossert, P.E., 2001, Cnidaria, in Thorp, J.H., and Covich, A.P., eds., Ecology and classification of North American freshwater invertebrates, 2nd edition: San Diego, Academic Press, p. 135-154.

Strother, P.K., 2000, Cryptospores: The origin and early evolution of the terrestrial flora, Gastaldo, R.A., and DiMichele, W.A., eds., Phanerozoic terrestrial ecosystems, in Paleontological Society Papers, v. 6, p. 3-20.

Thomas, M.A., Walsh, K.A., Wolf, M.R., McPheron, B.A., and Marden, J.H., 2000, Molecular phylogenetic analysis of evolutionary trends in stonefly wing structure and locomotor behavior: Proceedings of the National Academy of Sciences, USA, v. 97 , p. 13,178-13,183.

Thorp, J.H., and Covich, A.P., 2001, An overview of freshwater habitats, in Thorp, J.H., and Covich, A.P., eds., Ecology and classification of North American freshwater invertebrates, 2nd edition: San Diego, Academic Press, p. 19-41.

Tillyard, R.J., 1935, Upper Permian insects of New South Wales. V. The order Perlaria or stone-flies: Proceedings of the Linnean Society of New South Wales, v. 60, p. 385-391.

Toms, R.B., 1984, Were the first insects terrestrial or aquatic?: South African Journal of Science, v. 80, p. 319-323.

Tschernova, O.A., 1965, Some fossil mayflies (Ephemeroptera, Misthodotidae) from Permian beds of the Ural: Entomological Review, v. 44, no. 2, p. 202-207.

Vermeij, G.J., and Wesselingh, F.P., 2002, Neogastropod molluscs from the Miocene of western Amazonia, with comments on marine to freshwater transitions in molluscs: Journal of Paleontology, v. 76, p. 265-270.

Ward, J.V., 1992, Aquatic insect ecology 1. Biology and habitat: New York, John Wiley \& Sons, 438 p.

Wichard, W., Arens, W., and Eisenbeis, G., 2002, Biologica atlas of aquatic insects: Stenstrup, Denmark, Apollo Books, $339 \mathrm{p}$

Wootton, R.J., 1988, Historical ecology of aquatic insects: an overview: Palaeogeography, Palaeoclimatology, Palaeoecology, v. 52, p. 477-482.

Wotton, R.S., 1994, The biology of particles in aquatic systems, 2nd ed.: Boca Raton, Lewis Publishers, 325 p.

Manuscript received September 3, 2002, accepted October 8, 2002. 橉

\section{ERRATUM}

In our paper challenging the Noah's Flood Hypothesis for catastrophic flooding of the Black Sea (Aksu et al., 2002), proper acknowledgement was mistakenly not given to similar criticisms of this hypothesis in the literature. In particular, Çăgatay et al. (2000), Görür et al. (2001), and Algan et al. (2001) have all criticized the proposal of a catastrophic flood. The Aksu et al. (2002) "Outflow Hypothesis" differs in several ways from the scenarios presented by Cağatay et al. (2000) and Görür et al. (2001) and was based entirely on our own data and ideas. The similarities to Algan et al. (2001) are more embarrassing for us, but we had not read this paper when we submitted our manuscript to GSA Today. Nevertheless, we apologize to the authors of Çağatay et al. (2000), Görür et al. (2001), and Algan et al. (2001) for unjustifiably ignoring several of their important contributions to the evolution of the Black Sea-Marmara Sea-Aegean Sea oceanographic gateway. Ali E. Aksu and Richard N. Hiscott, Memorial University, Canada

\section{REFERENCES CITED}

Aksu, A.E., Hiscott, R.N., Mudie, P.J., Rochon, A., Kaminski, M.A., Abrajano, T., and Yaşar, D., 2002, Persistent Holocene outflow from the Black Sea to the eastern Mediterranean contradicts Noah's Flood Hypothesis: GSA Today, v. 12, no. 5, p. 4-10.

Algan, O., Çağatay, N., Tchepalyga, A., Ongan, D., Eastoe, C., and Gökaşan, E., 2001 Stratigraphy of the sediment infill in Bosphorus Strait: Water exchange between the Black and Mediterranean Seas during the last glacial Holocene: Geo-Marine Letters, v. 20, p. 209-218.

Çağatay, M.N., Görür, N., Algan, O., Eastoe, C., Tchepalyga, A., Ongan, D., Kuhn, T., and Kuşcu, I., 2000, Late Glacial-Holocene palaeoceanography of the Sea of Marmara: Timing of connections with the Mediterranean and the Black Seas: Marine Geology, v. 167, p. 191-206.

Görür, N., Çağatay, M.N., Emre, Ö, Alpar, B., Sakınç, M., Islamoğlu, Y., Algan, O., Erkal, T, Kecer, M. Akkök, R, and Karlık, G., 2001, Is the abrupt drowning of the Black Sea shelf at 7150 yrBP a myth?: Marine Geology, v. 176, p. 65-73. 